\title{
Non-medical use of methylphenidate: a review
}

\author{
Uso não terapêutico do metilfenidato: uma revisão
}

\author{
Luana Freese, ${ }^{1}$ Luciana Signor, ${ }^{2}$ Cassio Machado, ${ }^{3}$ Maristela Ferigolo, ${ }^{4}$ Helena Maria Tannhauser Barros ${ }^{5}$
}

\begin{abstract}
Introduction: Methylphenidate is a psychostimulant medication used for the treatment of attention deficit hyperactivity disorder and narcolepsy. However, it has also been used for non-medical purposes, e.g. to produce euphoria, to increase self-esteem, and to achieve the so-called neurocognitive enhancement, decreasing the feeling of tiredness and increasing focus and attention.

Objective: To describe, from theoretical and contextual points of view, the potential for abuse and non-medical use of methylphenidate. Method: The PubMed, SciELO and Cochrane databases were searched using the following keywords in Portuguese: metilfenidato, transtorno do déficit de atenção com hiperatividade, facilitadores dos processos cognitivos or agentes nootrópicos, and abuso de substâncias; and in English: methylphenidate, attention deficit disorder with hyperactivity, cognitive enhancement or nootropic agents, and substance abuse. Studies published between 1990 and 2010 were selected for review.

Results: Non-medical use of methylphenidate is a relevant topic that raises important ethical and scientific questions in several areas, e.g. pharmacological and neurobiological characteristics, evidence of methylphenidate use, forms of nonmedical use of methylphenidate, mechanisms of action, and therapeutic application of methylphenidate. According to the review, methylphenidate can generally influence performance as a result of its stimulatory effect. Notwithstanding, evidence does not support the conclusion that it can enhance cognitive performance.
\end{abstract}

Conclusion: Health professionals need to acquire expert knowledge and inform patients and their families on the methylphenidate potential for abuse when used with non-medical purposes.

Keywords: Methylphenidate, attention deficit disorder with hyperactivity, nootropic agents, substance-related disorders.

\section{Resumo}

Introdução: O metilfenidato é um medicamento psicoestimulante usado no tratamento do transtorno de déficit de atenção e hiperatividade e da narcolepsia. No entanto, a droga também vem sendo utilizada com fins não terapêuticos, por exemplo para produzir euforia, aumentar a autoestima e obter o chamado aprimoramento neurocognitivo, diminuindo a sensação de cansaço e aumentando o foco e a atenção.

Objetivo: Descrever, sob o ponto de vista teórico e contextual, o potencial de abuso do metilfenidato quando usado com fins não terapêuticos.

Método: Foi realizada uma pesquisa nos bancos de dados PubMed, SciELO e Cochrane, utilizando os seguintes termos em português: metilfenidato, transtorno do déficit de atenção com hiperatividade, facilitadores dos processos cognitivos or agentes nootrópicos e abuso de substâncias; e, em inglês: methylphenidate, attention deficit disorder with hyperactivity, cognitive enhancement or nootropic agents e substance abuse. Foram selecionados estudos publicados entre 1990 e 2010.

Resultados: $O$ uso não terapêutico do metilfenidato é um tema relevante e que suscita questões científicas e éticas importantes sob diversos aspectos, por exemplo características farmacológicas e neurobiológicas, evidência de uso da droga, formas não terapêuticas de uso, mecanismos de ação e aplicação terapêutica do metilfenidato. De acordo com a revisão o metilfenidato pode, em geral, influenciar o desempenho como resultado de seu efeito estimulatório. No entanto, independentemente disso, as evidências não apoiam a conclusão de que ele possa promover um melhor desempenho cognitivo. Conclusão: É importante que profissionais da saúde tenham conhecimento e informem os pacientes e suas famílias sobre o potencial de abuso do metilfenidato quando usado com fins não terapêuticos. Descritores: Metilfenidato, transtornos de déficit da atenção e do comportamento disruptivo, agentes nootrópicos, transtornos relacionados ao uso de substâncias.

\footnotetext{
${ }^{1}$ Biomédica. Mestranda, Programa de Pós-Graduação em Ciências da Saúde: Farmacologia e Terapêutica Clínica, Universidade Federal de Ciências da Saúde de Porto Alegre (UFCSPA), Porto Alegre, RS, Brazil. 2 Farmacêutica. Mestre, Ciências da Saúde, UFCSPA. Doutoranda, Programa de Pós-Graduação em Ciências da Saúde, UFCSPA. ${ }^{3}$ Acadêmico de Psicologia, Pontifícia Universidade Católica do Rio Grande do Sul (PUCRS), Porto Alegre, RS, Brazil. ${ }^{4}$ Farmacêutica, UFCSPA. Doutora em Ciências Médicas, Universidade Federal do Rio Grande do Sul (UFRGS), Porto Alegre, RS, Brazil. Coordenadora, Serviço Nacional de Informações e Orientações sobre a Prevenção do Uso Indevido de Drogas (VIVAVOZ). ${ }^{5}$ Médica. Pós-doutorado em Neuropsicofarmacologia, Tufts University, Boston, MA, USA. Professora titular, Farmacologia, UFCSPA. Coordenadora, VIVAVOZ.

Financial support: Coordenação de Aperfeiçoamento de Pessoal de Nível Superior (CAPES) and Conselho Nacional de Desenvolvimento Científico e Tecnológico (CNPq). Submitted Dec 08 2010, accepted for publication Nov 11 2011. No conflicts of interest declared concerning the publication of this article.

Suggested citation: Freese L, Signor L, Machado C, Ferigolo M, Barros HMT. Non-medical use of methylphenidate: a review. Trends Psychiatry Psychother. 2012;34(2):110-5.
} 


\section{Introduction}

Currently, methylphenidate (MPH) is the medication most frequently used for the treatment of attention deficit hyperactivity disorder (ADHD). The disorder primarily affects school-aged children, with an estimated prevalence ranging from 5 to $10 \%$ of the population. ${ }^{1}$ ADHD is characterized by behavioral symptoms associated with brain abnormalities and catecholaminergic system dysfunction. Main symptoms include difficulty focusing attention, hyperactivity, and increased impulsivity. ${ }^{2}$

$\mathrm{MPH}$ is also recognized as an alternative treatment option for narcolepsy. ${ }^{3}$ Less common indications include the treatment of depression in the elderly, cancer patients, ${ }^{4}$ and other cognitive disorders. ${ }^{5}$ There is also reference in the current literature about the use of MPH as

alternative supplement in abstinence maintenance treatment among users of psychostimulant drugs (e.g. cocaine and methamphetamine). However, results about the effectiveness of this latter use remain inconclusive. ${ }^{6,7}$

Several studies have expressed concern about the significant increase in $\mathrm{MPH}$ prescriptions in general, and about the greater risk of non-medical use of the substance in particular. ${ }^{1,8,9}$ According to the 1971 Convention on Psychotropic Substances, published by the International Narcotics Control Board (INCB) of the United Nations, ${ }^{10}$ the use of MPH requires special control measures. In Brazil, federal resolutions no. 344/1998 and $22 / 2001$ include $\mathrm{MPH}$ in the A3 category (psychotropic substances), and it is subject to controlled prescription as a result of the high risk of chemical dependence. ${ }^{11}$ These strategies represent attempts to restrict access of the general population (especially young individuals) to psychostimulant medications.

In Brazil, only one clinical report has so far described the case of a patient seeking treatment with $\mathrm{MPH}$ for non-medical purposes. ${ }^{12}$ Such scarcity of studies could lead to the belief that MPH abuse is uncommon. However, a recent web-based investigation ${ }^{13}$ revealed that the drug is widely mentioned and that its use without a prescription is promoted in blogs or social networks, with the main aim of enhancing cognitive performance.

In some countries, MPH is frequently used for nonmedical purposes, and most of these users take the drug without a prescription (they obtain the drug primarily through friends and relatives). ${ }^{14}$ One study conducted in the United States followed up children and adolescents who had been prescribed MPH. Approximately one in five of those patients were approached at least once over a 5 -year period and asked to sell, give away, or somehow share the medication. ${ }^{15}$

The present literature review aimed to review the scientific literature and collect data on non-medical uses of $\mathrm{MPH}$. The main neurobiological aspects underlying the use of MPH are discussed, as well as the mechanism of action and other pharmacological characteristics of the drug.

\section{Method}

The PubMed, SciELO, and Cochrane databases were searched using the following words in Portuguese: metilfenidato, transtorno do déficit de atenção com hiperatividade, facilitadores dos processos cognitivos or agentes nootrópicos, and abuso de substâncias; and the following in English: methylphenidate, attention deficit disorder with hyperactivity, cognitive enhancement or nootropic agents, and substance abuse. Studies published between 1990 and 2010 were selected for review. Books and journal articles cited in the reference lists of the selected studies were also reviewed and included in the analysis.

\section{Results and discussion}

\section{Pharmacology and toxicology}

\section{MPH classification and chemical characteristics}

The methyl alpha-phenyl-2-piperidylacetate (MPH) is a piperidine-derived psychostimulant of the amphetamine family that has been used for approximately 50 years. ${ }^{16}$

The molecular formula of $\mathrm{MPH}$ is $\mathrm{C}_{14} \mathrm{H}_{19} \mathrm{NO}_{2}$. It is a chiral substance, i.e., has enantiomers present in the molecule: (d)-methylphenidate and (I)-methylphenidate. Studies using positron-emission tomography (PET) have shown that $(d)$-enantiomer is the pharmacologically active compound, responsible for the pharmacological and adverse effects associated with the drug, once it bonds to dopamine transporters in the brain. ${ }^{17}$

\section{MPH pharmaceutical formulations}

$\mathrm{MPH}$ is commercially available in tablet or capsule forms for oral administration. Both immediate and extended release options (MPH-IR and MPH-ER, respectively) are available. $\mathrm{MPH}-\mathrm{IR}$ is available at a dose of $10 \mathrm{mg}$ and reaches peak plasma concentrations between 1 and 2 hours after administration $\left(T_{\max }\right)$, with a half-life $\left(T_{1 / 2}\right)$ of 2 to 3 hours. Usually, three or more daily doses of MPH-IR are necessary. ${ }^{3} \mathrm{MPH}-\mathrm{ER}$ presents two subtypes of substance release, namely the osmotic release oral system (OROS), available at doses of 18,36 , and $54 \mathrm{mg}$, and spheroidal oral drug absorption system (SODAS), at doses of 20,30, and $40 \mathrm{mg}$. In OROS, MPH is placed in slow-release capsules with effects lasting for up 
to 12 hours, allowing patients to take only daily dose. In SODAS, half the dose is placed in sugar spheres for IR, and the other half consists of granules placed in a polymer that will allow a second phase of absorption, approximately 4 hours after administration. Overall, the effect of SODAS $\mathrm{MPH}$ lasts for up to 8 hours, so more than one daily dose may be necessary. ${ }^{3}$ In Brazil, both IR and ER formulations are available: Ritalina ${ }^{\circledR}$ (MPH-IR), Ritalina LA ${ }^{\circledR}$ (SODAS) (MPH-ER), and Concerta ${ }^{\circledR}$ (OROS) (MPH-ER). ${ }^{18,19}$

When MPH-IR is used in the treatment of children with ADHD, the dose may vary from 0.3 to $0.7 \mathrm{mg} / \mathrm{kg}$, administered two to three times daily, i.e., 0.9 to 2.1 $\mathrm{mg} / \mathrm{kg} /$ day. Children younger than 6 years should not take $\mathrm{MPH}$. The standard dose for adults is 20 to $40 \mathrm{mg} /$ day, and it can be increased up to $60 \mathrm{mg} /$ day distributed in multiple daily administrations. The maximum daily does should not exceed $60 \mathrm{mg} /$ day, independently of the release system adopted, although in some cases higher doses may be required, ${ }^{3,5}$ e.g. overweight or tolerant patients; in the latter cases, the daily dose can be increased to $100 \mathrm{mg} /$ day with adequate response to treatment and no side effects. ${ }^{20}$

\section{Mechanism of action and the neurobiology of MPH abuse}

In the central nervous system, the mechanism of removal of neurotransmitters such as dopamine and norepinephrine depends primarily on the action of specific presynaptic transporters, such as dopamine transporters, whose role is to reuptake neurotransmitters, interrupting their effect. ${ }^{20}$ Psychostimulant drugs such as cocaine, amphetamines and $\mathrm{MPH}$ itself inhibit dopamine and norepinephrine transporters, increasing the availability of these neurotransmitters in synaptic clefts and thus producing stimulatory effects. It is estimated that an oral dose of $0.25 \mathrm{mg} / \mathrm{kg}$ of $\mathrm{MPH}$ is able to block $50 \%$ of dopamine transporters in humans (the plasma concentration corresponding to that blockade is $5.7 \mathrm{ng} /$ $\mathrm{mL}) .{ }^{21}$ Therefore, the standard daily dose would be able to block $50 \%$ of dopamine transporters.

The affinity of MPH for dopamine and norepinephrine transporters is higher than that of cocaine, for example. Thus, lower concentrations of MPH in target sites would be able to promote the same level of transporter blockade when compared with cocaine. ${ }^{9}$ From a different standpoint, however, MPH elimination is slower than cocaine elimination, precisely as a result of the increased affinity of the former for dopamine transporters. ${ }^{22}$ This is what limits the ability of MPH to promote a "high" effect with repeated use. ${ }^{17}$

MPH acts activating the main cortical and subcortical regions related with attention and executive functions. ${ }^{23}$ Because of the regional specificity of $\mathrm{MPH}$, it acts preferably on the striatum, prefrontal cortex, and nucleus accumbens. ${ }^{2,5,23}$ The accumulation of dopamine resulting from dopamine transporter blockade decreases reuptake rates and increases striatal cellular signaling. Thus, the action of MPH in the striatum would be clinically related with improved attention and decreased distraction. ${ }^{24}$ There is evidence that the action of MPH on the prefrontal cortex would be related primarily with noradrenergic modulation, ${ }^{15}$ thus promoting cognitive enhancement in working memory and associative learning. ${ }^{25}$ In the nucleus accumbens, the increase in dopamine seems to be related with increased motivation and consequently an improved task performance. ${ }^{9}$

The brain areas involved in the clinical effects of $\mathrm{MPH}$ are the same involved in the different mechanisms of chemical dependence, and the increased levels of dopamine found in areas of the limbic system are similar to the reinforcing effects observed for drugs of abuse. ${ }^{9}$ Therefore, caution is needed when administering medications that act on these regions.

\section{Pharmacokinetics}

$\mathrm{MPH}$ is immediately absorbed by the gastrointestinal tract, but it presents a low bioavailability, of about $30 \%$, once it goes through an extensive metabolism during the first passage. Maximum plasma levels are observed between 1.5 and 2.5 hours after oral administration of $\mathrm{MPH}-\mathrm{IR}$. MPH has a low affinity for plasma proteins, of approximately $15 \%$. However, its binding property is very strong. The $T_{1 / 2}$ of MPH-IR is of approximately 2.5 hours. ${ }^{3,9}$ The main transformation takes place in the liver, apparently as a result of the action of carboxylesterase- 1 (hCE-1) on the de-esterification of MPH to ritalinic acid, its main metabolite. ${ }^{24}$ About $75 \%$ of urinary excretion comprises ritalinic acid, compared to only $1 \%$ of unaltered $\mathrm{MPH} .{ }^{3,26}$ Another MPH metabolite, ethylphenidate, has also been used to detect intoxication resulting from the combination of $\mathrm{MPH}$ with alcohol. ${ }^{27}$

\section{Pharmacokinetics of abuse}

$\mathrm{MPH}$ may start out as a therapeutic agent and become a drug of abuse and addiction if used without prescription, at excessive doses, or outside a clinical setting, via either intranasal (tablet crushing and subsequent inhalation $)^{9,28}$ or intravenous administration (tablet dilution in water or other liquid medium). , $^{8,22}$ These two forms of administration of MPH can produce subjective rewarding or reinforcing effects, similar to those of cocaine, causing the individual to feel euphoric (or high). At the behavioral level of substance abuse, reinforcement is referred to as one of the most determinant aspects of drug dependence, suggesting that drugs that induce this mechanism have a greater potential for abuse. ${ }^{9}$ 
$\mathrm{T}_{\text {max }}$ or the time interval necessary for achieving peak plasma concentrations, represents another important parameter when distinguishing between clinical use and abuse of $\mathrm{MPH}$. $\mathrm{T}_{\max }$ differs drastically according to the administration route. In intravenous administration, and to a lesser extent in intranasal administration, $T_{\max }$ is reached almost instantaneously, producing an euphoric effect. Conversely, after oral administration, $\mathrm{T}_{\max }$ is reached about 1.5 to 2.5 hours after intake, as a result of the absorption process in the stomach and intestines. ${ }^{9}$

Thus, the effects of MPH in clinical and non-clinical uses seem to be related to the regulation of the pharmacokinetic profile of the drug. ${ }^{9,17}$ In our literature review, all articles describing $\mathrm{MPH}$ abuse focused on the use of MPH-IR. ${ }^{8,9,14}$

\section{Evidence in the treatment of ADHD and narcolepsy}

ADHD may have a chronic evolution, with symptoms that persist into adult life in up to $65 \%$ of cases, ${ }^{29}$ and there is evidence attesting to the effectiveness of $\mathrm{MPH}$ in the treatment of this disorder. ${ }^{2,3,9,18,26} \mathrm{~A}$ previous study describing the treatment of school-aged ADHD children reported effective results of $\mathrm{MPH}$ in controlling symptoms, with more expressive results observed for attention, distraction, impulsivity, and school social/ behavioral measures. Less expressive effects were found in the assessment of academic performance. Direct comparisons with other stimulant drugs have not revealed differences. ${ }^{30}$

Currently, the literature is seeking evidence of the effects of MPH on more complex cognitive responses. A study describing the use of the Cambridge Gamble Task (CGT) (Cambridge Neuropsychological Test Automated Battery $[\mathrm{CANTAB}]$ ) has demonstrated that $\mathrm{MPH}$ reduced risk-prone betting behavior on the CGT. MPH was observed to significantly reduce gambling behaviors, which may be seen as related with impulsivity. ${ }^{31}$

Adults with ADHD present deficiency in several cognitive domains, e.g. sustained attention, executive functions, working memory, and response inhibition. These characteristics can result in unfavorable decisions and consequently an increased risk for substance abuse, dangerous driving, professional instability, and difficulty maintaining stable relationships. ${ }^{32} \mathrm{MPH}$ shows important clinical benefits for these patients, ${ }^{33}$ and it is the main drug currently available for the treatment of adults with ADHD in Brazil. ${ }^{18}$

MPH has been shown to improve spatial working memory performance in youngsters and adults with ADHD: most patients taking the drug are less likely to make mistakes when performing a proposed task. ${ }^{27,33} \mathrm{~A}$ meta-analysis focusing on the treatment of adults with ADHD with $\mathrm{MPH}$ has revealed a statistically significant effect of the drug when treatment is optimized to high doses. ${ }^{34}$ Another broader and better-designed metaanalysis has found a considerably lower effect size, suggesting caution in the selection of MPH as the firstline and only treatment choice. ${ }^{35}$ Based on these lower yet significant results, those authors advocate the use of psychostimulants for the treatment of adults with ADHD, but also emphasize that the current uncertainty about long-term psychiatric and physical effects of MPH should be taken into account when choosing the best therapy. ${ }^{35}$

Because of the psychostimulant properties of $\mathrm{MPH}$, it can also be used in the treatment of narcolepsy. 3,36 There are studies reporting objective improvement of sleepiness in 65 to $85 \%$ of individuals under treatment. ${ }^{36}$

\section{Evidence of neurocognitive enhancement}

The availability of drugs capable of enhancing the normal human being's ability to retain information represents an important turning point in the study of memory and learning. As a result, expectations have been raised about the enhancement of learning processes in healthy people through medications. Epidemiological data from different studies point to an increased use of psychostimulant drugs among students with the aim of improving academic performance. 8,15,37,38

Learning and memory are defined as the ability to acquire new information and retain them via the combined action of multiple cognitive and neural systems. Despite the fact that there are no independent operations in the memorization process, there are some specific areas, e.g. working memory, which provides a reservoir for the preservation of transient memories. This reservoir can be understood as the space where evoked information is effectively used, allowing cognitive processes such as comprehension, learning, and logical thinking to take place. ${ }^{39}$

A previous study employing neuroimaging techniques in an attempt to establish a relationship between $\mathrm{MPH}$ action and an improved working memory in healthy individuals has found that the phenomenon results from the action of $\mathrm{MPH}$ on the prefrontal cortex. ${ }^{26} \mathrm{~A}$ metaanalysis has also found results that suggest an improved working memory in this population, although the data and analyses available do not allow definitive conclusions. ${ }^{37}$ It is therefore necessary to be cautious when attesting that cognitive enhancement can be achieved in healthy subjects, especially because of individual characteristics that should always be carefully taken into account. Genetic variations of the catechol-O-methyltransferase (COMT) polymorphism, for example, affect basal 
dopamine levels and result in different levels of dopamine across subjects. People with a high COMT activity have lower dopamine levels and vice versa. The action of psychostimulant medications in groups with low COMT activity would therefore provoke an excessive increase in dopamine levels and consequently allow subjects to develop the ability to stabilize and maintain an adequate task performance (cognitive stability). Conversely, normal levels of dopamine would maintain the subject's ability to update information (cognitive flexibility). In both cases, the individual's ability to absorb and coherently select data received during the performance of tasks with highlevel cognitive demands is maintained. ${ }^{38,39}$

Another study investigating long-term memory has suggested that MPH improves long-term information retention if the drug is active when the memory is being consolidated. However, this also significantly occurs in situations where there is an impaired retention of information. In other words, MPH can improve memory in situations where performance is already compromised. ${ }^{38}$

It is important to highlight that different levels of neurotransmitters are present in different brain regions. So, even when some functions show improvement after the administration of drugs such as $\mathrm{MPH}$, other functions may be impaired. ${ }^{40}$ These and other findings suggest that inducing the increase of certain neurotransmitters through the use of stimulant agents improves the performance of patients with cognitive compromise, but may not have any effect or cause any damage to other subjects. ${ }^{33,37,38}$ However, dose-dependent cardiovascular adverse effects have also been observed. ${ }^{26}$

\section{MPH adverse effects and risks}

The following adverse effects are most frequently reported in association with MPH: angina, arrhythmia, palpitations, and tachycardia in the cardiovascular system; aggressiveness, agitation, confusion, headache, tremors, and mood swings in the central nervous system; abdominal pain, loss of appetite, anorexia, and nausea in the gastrointestinal system. All these effects are expected for any psychostimulants that act as dopamine or norepinephrine reuptake inhibitors. ${ }^{3}$

The toxic manifestations of MPH are compatible with those typically described for peripheral sympathomimetic drugs: hyperthermia, euphoria, delirium, hallucinations, and seizures. ${ }^{41}$ In MPH-naive subjects, the toxic dose may be very close to the therapeutic dose when compared with patients under long-term treatment. Cases of intoxication have been described after the administration of chewed or crushed tablets at doses ranging from 2 $\mathrm{mg} / \mathrm{kg}$ or $60 \mathrm{mg}$ for MPH-IR to $4 \mathrm{mg} / \mathrm{kg}$ or $120 \mathrm{mg}$ for $\mathrm{MPH}-\mathrm{ER} .{ }^{42}$ Conversely, several studies on the clinical use of MPH attest to its effectiveness and low toxicity, ${ }^{3,18,25,30}$ and recommend its use with a personalized medical prescription.

$\mathrm{MPH}$ abuse (intravenous or inhalation routes) provokes intoxication effects such as hypertension, tachycardia, agitation, paranoia, delirium, and hyperactivity. After the long-term use of $\mathrm{MPH}$, symptoms such as tolerance, compulsive drug use, anorexia, personality changes, depression, and abstinence may be observed. ${ }^{29}$

Rational prescription of drugs implies the indication of formulae with a lower potential for abuse and the investigation of previous occurrences of drug abuse in each patient, among other recommendations. Also, once the clinical use of MPH is more frequent among children, parents and the school should be aware of the potential for abuse and of misuse of MPH, i.e., receive instructions on adequate doses and storage. ${ }^{2}$

\section{Conclusion}

The recent increase in MPH prescriptions has expanded the availability of the drug for non-medical uses. Although this fact is widely known among health professionals, the consequences of such use have been little explored.

The present study aimed to describe, from pharmacological and neurobiological points of view, the non-medical forms of use of $\mathrm{MPH}$, evidence of MPH use, mechanisms of action, and the therapeutic application of $\mathrm{MPH}$. Our findings revealed that this is a relevant topic under different perspectives, given the importance of expert knowledge among health professionals regarding the occurrence and consequences of non-medical uses of $\mathrm{MPH}$. This scenario underscores the need for rational prescription, pharmaceutical care, and shared knowledge about the use and storage of this drug among patients and their families.

\section{References}

1. Gumy C, Huissoud T, Dubois-Arber F. Prevalence of methylphenidate prescription among school-aged children in a Swiss population: increase in the number of prescriptions in the Swiss Canton of Vaud, from 2002 to 2005, and changes in patient demographics. J Atten Disord. 2010;14:267-72.

2. Pliszka SR. The neuropsychopharmacology of attention-deficit/ hyperactivity disorder. Biol Psychiatry. 2005;57:1385-90.

3. The British Pharmacopeia. 6th ed. London: Queen's Road; 2009.

4. Moraska AR, Sood A, Dakhil SR, Sloan JA, Barton D, Atherton $\mathrm{PJ}$, et al. Phase III, randomized, double-blind, placebocontrolled study of long-acting methylphenidate for cancerrelated fatigue: North Central Cancer Treatment. J Clin Oncol. 2010;28:3673-9.

5. Challan TD, Lipsky J]. Methylphenidate: its pharmacology and uses. Mayo Clin Proc. 2000;75:711-21. 
6. Castells X, Casas M, Pérez-Mañá C, Roncero C, Vidal X, Capellà D. Efficacy of psychostimulant drugs for cocaine dependence. Cochrane Database Syst Rev. 2010;17:CD007380.

7. Volkow ND, Wang GJ, Tomasi D, Telang F, Fowler JS, Pradhan $\mathrm{K}$, et al. Methylphenidate attenuates limbic brain inhibition after cocaine-cues exposure in cocaine abusers. PLoS One. 2010;5:e11509.

8. Farquhar $S$, Fawcett $P$, Fountain F. Illicit intravenous use of methylphenidate (ritalin) tablets: a review of four cases. Aust Emerg Nurs J. 2002; 5:25-9.

9. Volkow ND, Swanson JM. Variables that affect the clinical use and abuse of methylphenidate in the treatment of ADHD. Am J Psychiatry. 2003;160:1909-18.

10. United Nations, International Narcotics Control Board. Convention on psychotropic substances, 1971. New York: UN; 1971. http://www.incb.org/pdf/e/conv/convention_1971 en.pdf. Accessed 2012 Apr 16.

11. Carlini EA, Nappo SA, Nogueira V, Naylor FGM. Metilfenidato: influência da notificação de receita $A$ (cor amarela) sobre a prática de prescrição por médicos brasileiros. Rev Psiquiatr Clin. 2003;30:11-20.

12. Victor M. Expansores cognitivos e psiquiatria cosmética: estamos preparados? Relato de caso. Rev Bras Psiquiatr. 2009;31:387-95.

13. Barros DB. Aprimoramento cognitivo farmacológico - grupos focais com universitários [dissertação]. Rio de Janeiro: UERJ; 2009.

14. Musser CJ, Ahmman PA, Theye FW. Stimulant use and the potential for abuse in Wisconsin as reported by school administration an longitudinally followed children. J Dev Behav Pediatr. 1998;19:187-9.

15. Wilens TE, Adler LA, Adams J, Sgambati S, Rotrosen J, Sawtelle R, et al. Misuse and diversion of stimulants prescribed for ADHD: a systematic review of the literature. J Am Acad Child Adolesc Psychiatry. 2008;47:21-31.

16. National Center for Biotechnology Information. Methylphenidate Substance Summary. Rockville: NCBI; 2009. http://pubchem.ncbi. $\mathrm{nlm}$.nih.gov/summary/summary.cgi?sid $=48416258 \&$ loc $=$ es_rss. Accessed 2012 Apr 16.

17. Volkow ND, Wang GJ, Fowler JS, Ding YS. Imaging the effects of methylphenidate on brain dopamine: new model on its therapeutic actions for attention-deficit/hyperactivity disorder. Biol Psychiatry. 2005;57:1410-5.

18. Louzã MR, Mattos P. Questões atuais no tratamento farmacológico do TDAH em adultos com metilfenidato. J Bras Psiquiatr. 2007; 56:53-6.

19. Swanson JM, Volkow ND. Serum and brain concentrations of methylphenidate: implications for use and abuse. Neurosci Biobehav Rev. 2003;27:615-21.

20. Biederman J, Mick E, Surman C, Doyle R, Hammerness P, Harpold $T$, et al. A randomized, placebo-controlled trial of OROS methylphenidate in adults with attention-deficit/ hyperactivity disorder. Biol Psychiatry. 2006;59:829-35. Erratum in: Biol Psychiatry. 2007;61:1402.

21. Volkow ND, Wang GJ, Fowler JS, Gatley SJ, Logan J, Ding YS, et al. Dopamine transporter occupancies in the human brain induced by therapeutic doses of oral methylphenidate. Am J Psychiatry. 1998;155:1325-31.

22. Gatley SJ, Volkow ND, Gifford AN, Fowler JS, Dewey SL, Ding YS, et al. Dopamine-transporter occupancy after intravenous doses of cocaine and methylphenidate in mice and humans. Psychopharmacology (Berl). 1999;146:93-100.

23. Levy F. Pharmacological and therapeutic directions in ADHD: specificity in the PFC. Behav Brain Funct. 2008;4:12.

24. Volkow ND, Wang G, Fowler JS, Logan J, Gerasimov M, Maynard $\mathrm{L}$, et al. Therapeutic doses of oral methylphenidate significantly increase extracellular dopamine in the human brain. J Neurosci. 2001;21:RC121.

25. Mehta MA, Owen AM, Sahakian BJ, Mavaddat N, Pickard JD, Robbins TW. Methylphenidate enhances working memory by modulating discrete frontal and parietal lobe regions in the human brain. J Neurosci. 2000;20:RC65.

26. Pattij T, Vanderschuren LJ. The neuropharmacology of impulsive behavior. Trends Pharmacol Sci. 2008;29:192-9.

27. Koehm M, Kauert GF, Toennes SW. Influence of ethanol on the pharmacokinetics of methylphenidate's metabolites ritalinic acid and ethylphenidate. Arzneimittelforschung. 2010;60:238-44.

28. Parran TV, Jasinski DR. Intravenous methylphenidate abuse: prototype for prescription drug abuse. Arch Intern Med. 1991;151:781-3.

29. Biederman J, Monuteaux MC, Spencer T, Wilens $T E$, MacPherson HA, Faraone SV. Stimulant therapy and risk for subsequent substance use disorders in male adults with ADHD: a naturalistic controlled 10-year follow-up study. Am J Psychiatry. 2008;165:597-603.

30. Brown RT, Amler RW, Freeman WS, Perrin JM, Stein MT, Feldman HM, et al. Treatment of attention-deficit/hyperactivity disorder: overview of the evidence. Pediatrics. 2005;115:749-57.

31. DeVito EE, Blackwell AD, Kent L, Ersche KD, Clark L, Salmond $\mathrm{CH}$, et al. The effects of methylphenidate on decision making in attention-deficit/hyperactivity disorder. Biol Psychiatry. 2008;64:636-9.

32. Agay N, Yechiam E, Carmel Z, Levkovitz Y. Non-specific effects of methylphenidate (Ritalin) on cognitive ability and decisionmaking of ADHD and healthy adults. Psychopharmacology (Berl). 2010;210:511-9

33. Turner DC, Blackwell AD, Dowson JH, McLean A, Sahakian BJ. Neurocognitive effects of methylphenidate in adult attentiondeficit/hyperactivity disorder. Psychopharmacology (Berl). 2005; 178:286-95.

34. Faraone SV, Spencer T, Aleardi M, Pagano C, Biederman J. Meta-analysis of the efficacy of methylphenidate for treating adult attention-deficit/hyperactivity disorder. J Clin Psychopharmacol. 2004;24:24-9.

35. Koesters M, Becker T, Kilian R, Fegert JM, Weinmann S. Limits of meta-analysis: methylphenidate in the treatment of adult attention-deficit hyperactivity disorder. J Psychopharmacol. 2009; $23: 733$

36. Mitler MM, Aldrich MS, Koob GF, Zarcone VP. Narcolepsy and its treatment with stimulants. ASDA standards of practice. Sleep. 1994;17:352-71.

37. Repantis D, Schlattmann $P$, Laisney $O$, Heuser I. Modafinil and methylphenidate for neuroenhancement in healthy individuals: a systematic review. Pharmacol Res. 2010;62:187-206.

38. Advokat $C$. What are the cognitive effects of stimulant medications? Emphasis on adults with attention-deficit/ hyperactivity disorder (ADHD). Neurosci Biobehav Rev. 2010;34:1256-66.

39. Kandel ER. Cellular mechanisms of learning and the biological basis of individuality. In: Kandel ER, Schwartz JH, Jessell TM, editors. Principles of neural science. Norwalk: Appleton \& Lange; 1991. p. 1009-31.

40. Cools R, Robbins TW. Chemistry of the adaptive mind. Philosophical transactions. Philos Transact A Math Phys Eng Sci. 2004;362:2871-88.

41. Klein-Schwartz W, McGrath J. Poison centers' experience with methylphenidate abuse in pre-teens and adolescents. J Am Acad Child Adolesc Psychiatry. 2003;42:288-94.

42. Scharman EJ, Erdman AR, Cobaugh DJ, Olson KR, Woolf AD, Caravati EM, et al. Methylphenidate poisoning: an evidencebased consensus guideline for out-of-hospital management. Clin Toxicol (Phila). 2007;45:737-52.

\section{Correspondence}

Luana Freese

Rua Sarmento Leite, 245, 30 andar

90050-170 - Porto Alegre, RS - Brazil

Tel. : +55 (51) 3303.8764

Fax: +55 (51) 3303.8764

E-mail: lufreese@gmail.com 